\title{
COLONY COMPOSITION AND BIOMASS OF MACROTERMES GILVUS HAGEN (BLATTODEA: TERMITIDAE) IN INDONESIA
}

\author{
NiKen SubeKTI $^{1 *}$, PriYANTINi WidiYANINGRUM ${ }^{2}$, Dodi NANDIKA ${ }^{3}$ \\ AND DEDY DURYADI SOLIKHIN ${ }^{3}$ \\ ${ }^{1,2}$ Biology Department, Semarang State University, Semarang, Indonesia. \\ ${ }^{3}$ Forestry Department, Bogor Agricultural University, Bogor, Indonesia. \\ ${ }^{4}$ Biology Department, Bogor Agricultural University, Bogor, Indonesia. \\ "Corresponding author: nikensubekti@mail.unnes.ac.id \\ (Received: $4^{\text {th }}$ Dec 2018; Accepted: $4^{\text {th }}$ April 2019; Published on-line: $1^{\text {st }}$ June 2019) \\ https://doi.org/10.31436/iiumej.v20i1.1032
}

\begin{abstract}
There is no study conducted to investigate the composition and biomass of Macrotermes gilvus Hagen in natural forest ecosystem. This study aimed to analyze the colony composition and biomass of M. gilvus Hagen colony in natural forest and to evaluate the need of food of the species as well as factors affecting it. Research was conducted in Yanlappa Sanctuary, Bogor, West Java. Termites were surveyed by collecting individual $M$. gilvus Hagen from different colony at different size of mound, small $(0-0.99 \mathrm{~m})$, medium $(1-1.99 \mathrm{~m})$, large $(\geq 2 \mathrm{~m})$ and then were measured the number of individuals, wet and dry body mass, ratio of dry or wet body mass, and the average of biomass. Results indicated that the small mount was dominated by workers, whereas the medium and the large nest was dominated by nymph. Mean of the termite biomass was $936 \mathrm{~kg} / \mathrm{ha}^{2}$. Average of termite biomass collected from large mount was $949.8 \mathrm{~kg} / \mathrm{km} 2$, medium mount was $605.2 \mathrm{~kg} / \mathrm{ha}^{2}$ and small mount was about 537.5 $\mathrm{kg} / \mathrm{ha}^{2}$. Factor affecting the biomass of subterranean termite M. gilvus Hagen are food source, energy efficiency, predators, and environment. The presence of termite mounds influences natural ecosystem, but that the type of mound plays a crucial role in determining the nature of the effects.
\end{abstract}

ABSTRAK: Kajian tentang komposisi koloni dan biomas anai-anai tanah M. gilvus Hagen di ekosistem hutan semulajadi belum pernah dilakukan. Kajian ini bertujuan bagi menganalisa komposisi koloni dan biomas koloni anai-anai tanah M. gilvus Hagen di hutan semulajadi dan menganalisa keperluan makanan spesis ini serta faktor-faktor yang mempengaruhi pemakanannya. Kajian ini dijalankan di Cagar Alam Yanlappa, Bogor, Jawa Barat. Anai-anai ini dikaji dengan mengumpul setiap M. gilvus Hagen dari koloni berbeza berdasarkan pada ketinggian sarang, iaitu sarang kecil $(0-0.99 \mathrm{~m})$, sarang sederhana (1- $1.99 \mathrm{~m})$, dan sarang besar ( $\geq 2 \mathrm{~m}$ ). Kemudian, setiap koloni ini diukur berat basah, berat kering serta nisbah berat basah atau berat kering, dan purata biomas. Hasil kajian menunjukkan bahawa sarang kecil di dominasi oleh koloni pekerja, sementara sarang sederhana dan sarang besar di dominasi oleh koloni nympha. Purata biomas anai-anai dari sarang besar adalah $949.8 \mathrm{~kg} / \mathrm{ha}^{2}$, sarang sederhana $605.2 \mathrm{~kg} / \mathrm{ha}{ }^{2}$, dan sarang kecil $537.5 \mathrm{~kg} / \mathrm{ha}^{2}$. Faktor-faktor yang mempengaruhi biomas anai-anai tanah M. gilvus Hagen adalah sumber pemakanan, tenaga, pemangsa dan faktor sekeliling. Kehadiran koloni anai-anai mempengaruhi ekosistem semulajadi, tetapi jenis koloni memainkan peranan penting dalam menentukan sifat kesannya.

KEYWORDS: biomass; colony; Macrotermes gilvus Hagen 


\section{INTRODUCTION}

Macrotermes gilvus Hagen has an important role in natural ecosystem, particularly in nutrient cycling as an active decomposer. Moreover, this species of Termitidae is a crucial component of biogeochemical cycles [1], especially carbon and nitrogen cycle [2]. $M$. gilvus Hagen is widely spread in Southeast Asia, especially in Indonesia. It is one of the subterranean termites consuming much litter and other cellulosic material within the forest. However, there is no more information concerning to its biological study in Indonesian natural forest. One parameter associated to those biological roles in certain ecosystem is biomass, a quantitative measurement of total mass of termite from a part or all member of a population in a certain place and time. Biomass of this species can change over time, and this certainly depends on colony composition within the colony. Biomass is possible to be used as an appropriate indicator to measure the number of food consumed by this species, hence it can be predicted the effects of the species in an ecosystem [3]. No studies have been conducted to investigate the biomass of M. gilvus Hagen in Indonesian natural forest ecosystem. Therefore, research on biomass and colony composition is crucial and needed especially in the field of biology of M. gilvus Hagen in the current natural ecosystem. The objective of this research was to study the M. gilvus Hagen biomass in natural forest and to evaluate the need of food of the species along with the factors affecting it. Biomass is the amount of living matter present at any given time, expressed as mass per unit area or volume of habitat. Given the ubiquitous and wide spread distribution of termites throughout savannahs and biomasses estimated to equal that of large herbivores, this nutrient enrichment through mound erosion may contribute significantly to vegetation heterogeneity in savannahs [4]. This present study focused to observe various variables including wet and dry body mass, ratio of dry body mass/wet body mass, and average of biomass based on the mound size of M. gilvus Hagen.

\section{MATERIALS AND METHODS}

This research was performed in Yanlappa Sanctuary, Bogor, West Java (located between $6^{\circ} 40^{\prime} \mathrm{S}$ and $106^{\circ} 45^{\prime} \mathrm{E}$. The selection of the area was based on the high density of termite $M$. gilvus Hagen mound after a census. Subterranean termites M. gilvus Hagen samplings were conducted by using colony classification [3] at different size of mound: small mound height $(0-0.99 \mathrm{~m})$, medium mound height $(1-2.99 \mathrm{~m})$ and large mound height $(\geq 3 \mathrm{~m})$ [2]. Height mound means size mound from land surface to on top of mound. Furthermore, the procedure was continued by calculated the colony termites composition in the mound. It was obtained by digging and dismantling the mound vertically and horizontally at as much 3 of each nest type. Termite specimens of each sample mound were then collected using vacuum cleaner (3.5 kVA). After dismantled, the mound were then closed using dark plastic for 3 hours to give the remaining time for termite foragers back to the nest. All specimens were subsequently dried in $100{ }^{\circ} \mathrm{C}$ oven for 24 hours. Dried specimens were then measured for each colony to obtain the dry body mass value. All materials were cooled and stored in desiccator and balanced. All measurements were replicated 10 times.

\section{RESULTS AND DISCUSSION}

Results showed that large mound had ten times higher colony size than small mound, whereas medium mound had four times higher than small mound. The comparison between colonies in small and large mound was consistent, while in the medium mound, the number of major soldier was strongly high. The small mound was dominated by 
workers, whereas the medium and the large mound was dominated by nymph (Table 1). AVONA and correlation test presented that there was a significant correlation between the number of individuals and the mound size.

Table 1: The number of individuals in termite colony at three different types of mounds, Yanlappa sanctuary, Bogor

\begin{tabular}{cccccc}
\hline $\begin{array}{c}\text { Colony } \\
\text { Nest type }\end{array}$ & $\begin{array}{c}\text { Major } \\
\text { Soldier }\end{array}$ & $\begin{array}{c}\text { Minor } \\
\text { Soldier }\end{array}$ & Worker & Nymph & Total \\
\hline Small & $1,297 \pm 179$ & $261 \pm 91$ & $10,196 \pm 1,455$ & $8,468 \pm 210$ & $20,223 \pm 1,919$ \\
Medium & $4,021 \pm 289$ & $906 \pm 573$ & $3,167 \pm 706$ & $38,173 \pm 645$ & $46,267 \pm 2,073$ \\
Large & $2,964 \pm 158$ & $360 \pm 423$ & $29,277 \pm 183$ & $151,233 \pm 8,24$ & $183,825 \pm 7,742$ \\
\hline
\end{tabular}

Table 2: Wet and dry body mass of Macrotermes gilvus Hagen in natural forest, Yanlappa Sanctuary, Bogor $(\mathrm{n}=300)$

\begin{tabular}{cccc}
\hline $\begin{array}{c}\text { Colony / Sub } \\
\text { Colony }\end{array}$ & Wet body mass $(\mathrm{g})$ & $\begin{array}{c}\text { Dry body mass } \\
(\mathbf{g})\end{array}$ & $\begin{array}{c}\text { Ratio Dry body mass/ } \\
\text { Wet Body mass (\%) }\end{array}$ \\
\hline Worker & $6.08 \pm 18.06$ & $3.63 \pm 7.17$ & $59,70 \pm 10.27$ \\
Major Soldier & $33.30 \pm 39.31$ & $14.37 \pm 16.89$ & $43,15 \pm 31.20$ \\
Minor Soldier & $8.43 \pm 20.69$ & $6.60 \pm 13.76$ & $78,29 \pm 14.24$ \\
Nymph & $8.67 \pm 14.84$ & $6.23 \pm 7.16$ & $71,85 \pm 9.52$ \\
Queen & $1,082.30 \pm 66.70$ & $444.10 \pm 14.01$ & $41.03 \pm 17.78$ \\
King & $1,038.80 \pm 10.75$ & $654.20 \pm 67.54$ & $63.00 \pm 61.99$ \\
\hline
\end{tabular}

In the study area, there were 43 points of termite colonies consisted of 15 spots of large mound, 23 spots of medium mound, and 5 spots of small mound. Termite biomass M. gilvus Hagen found in the study area was approximately $936 \mathrm{~kg} / \mathrm{ha}^{2}$ with biomass average for small mound was $537.5 \mathrm{~kg} / \mathrm{ha}^{2}$, medium mound was $605.2 \mathrm{~kg} / \mathrm{ha}^{2}$, and large mound was $949.8 \mathrm{~kg} / \mathrm{ha}^{2}$ (Table 3). This variation is due to the size and age of the individuals of mound. The traps which were installed near the colony were found to have adult workers, soldiers as well as nymphs and therefore a large number of individuals were recorded in 1 mound sample [5].

Table 3: Mean of biomass for each colony based on the size mound of Macrotermes gilvus Hagen in natural forest

\begin{tabular}{cccc}
\hline \multirow{2}{*}{ Colony/Sub colony } & \multicolumn{3}{c}{ Biomass for each mounds (kg/ha) } \\
\cline { 2 - 4 } & Small & Medium & Large \\
\hline Worker & $2.458 \pm 2.788$ & $2.524 \pm 3.104$ & $5.517 \pm 8.666$ \\
Major soldier & $9.058 \pm 10.375$ & $10.135 \pm 11.261$ & $11.414 \pm 13.164$ \\
Minor soldier & $2.575 \pm 3.153$ & $3.175 \pm 3.431$ & $3.681 \pm 4.033$ \\
Nymph & $0.764 \pm 1.361$ & $1.192 \pm 1.614$ & $5.517 \pm 8.666$ \\
\hline \multirow{2}{*}{ Total } & $\mathbf{5 . 3 7 5}$ & $\mathbf{6 . 0 5 2}$ & $\mathbf{9 . 4 9 8}$ \\
& $\mathbf{5 3 7 . 5} \mathbf{~ k g} / \mathbf{h a}^{\mathbf{2}}$ & $\mathbf{6 0 5 . 2} \mathbf{~ k g} / \mathbf{h a}^{\mathbf{2}}$ & $\mathbf{9 4 9 . 8} \mathbf{~ k g} / \mathbf{h a}^{\mathbf{2}}$ \\
\hline
\end{tabular}

The highest biomass of M. gilvus Hagen was recorded in major soldiers, and then followed by minor soldier, worker, and nymph. The highest number of biomass of major soldier may be related to its contribution to the colony that is smaller compared with minor soldier and worker colony. In the present study, number of workers was found to be higher 
compared with other colonies with its portion was about $80 \%$ of the total colony. The colony composition in social insects can be influenced by environmental factors such as temperature. Furthermore, colony composition in termite colony or foraging groups of termites are known to vary with time of day, season, species, and colony size or age [6]. Meanwhile, individual shifting was faster in worker colony compared with soldier. The soldier was reported to live longer than the others [3].

In a colony, worker is responsible for various kinds of tasks including food foraging and feeding other colonies, repairing the nest, and also building new nests. It also helps to control air circulation especially for $\mathrm{CH}_{4}$ and $\mathrm{CO}_{2}$, to maintain fungus plantation, as well as controlling mound humidity [4]. The smallest biomass was recorded for nymph, which may be related to phenology of termite since nymph is immature phase that is still growing to become mature termite with certain function for the colony. Foods consumed by termites are not only used for growth and energy but they are also stored inside termite's gut. Feces and water secreted from the body are also converted into energy, tissue, organ, and another use [5]. The worker's gut fungus-growing subterranean termites (Macrotermes) secreted enzymes used for final oligosaccharides digestion [7]. Gut of subterranean termites M. gilvus Hagen worker was in alkaline condition ( $\mathrm{pH} 8.83 \pm 0.31$ ) and strongly supported the lignocellulose digestion [8]. These workers also transported enzymes from mature fungi to the inoculated plant substrate [9]. Environmental factor has a strong relationship with termite biomass. Higher number of M. gilvus Hagen biomass might be related to their habitats in the tropic with abundant food around it and high level of decomposition, which result in low level of energy utilization. Fewer predators around the colony will result in more efficient of energy utilization compared with lots of predator living around it [10].

\section{CONCLUSION}

This study concludes that the small mound was dominated by workers, whereas the medium and the large mound was dominated by nymph. The mean of M. gilvus Hagen biomass reached $936 \mathrm{~kg} / \mathrm{ha}^{2}$. Mean of termite biomass M. gilvus Hagen for large mound was $949.8 \mathrm{~kg} / \mathrm{ha}^{2}$, medium mound was $605.2 \mathrm{~kg} / \mathrm{ha}^{2}$ and small mound was $537.5 \mathrm{~kg} / \mathrm{ha}^{2}$. The variation in percent workers colony suggests that environmental factors such temperature; relative humidity and rainfall affect the ratio of the workers to soldiers.

\section{ACKNOWLEDGEMENT}

This work was financially supported by the Ministry of Research, Technology and Higher Education of the Republic of Indonesia through Universitas Negeri Semarang, Semarang, Indonesia.

\section{REFERENCES}

[1] Brune A. (2014). Symbiotic digestion of lignocellulose in termite guts. Nat. Rev. Microbiol., 12(3): 168-180.

[2] Meyer VW, Crewe RM, Braack LEO, Groeneveld HT, Linde MJ. (2001). Biomass of Macrotermes natalensis in the Northern Kruger National Park, South Africa-The Effects of Land Characteristics. J. Sociobiol., 38(3): 431-448.

[3] Turner JS. (2006). Termites as mediators of the water economy of arid savanna ecosystems. In Dryland Ecohydrology (pp. 303-313). Springer, Dordrecht. 
[4] Cleo MG, Joris PGM, Cromsigt, Mpanza N, Olff H. (2012). Effects of Erosion from Mounds of Different Termite Genera on Distinct Functional Grassland Types in an African Savannah. Ecosystems, 15: 128-139.

[5] Strassmann JE, Queller DC. (2007). Insect Societies as Divided Organisms: The Complexities of Purpose and Cross-Purpose. Department of Ecology and Evolutionary Biology, Rice University, Houston USA

[6] Sattar A, Naeem M, Ul Haq E. (2013). Impact of environmental factors on the population dynamics, density and foraging activities of Odontotermes lokanandi and Microtermes obesi in Islamabad. SpringerPlus, 2: 349

[7] Poulsen M, Hu H, Li C, Chen Z, Xu L, Otani S, Nygaard S, Nobre T, Klaubauf S, Schindler P M, Hauser F. (2014). Complementary symbiont contributions to plant decomposition in a fungus-farming termite. PNAS, 111(40): 14500-14505.

[8] Subekti N, Fibriana F, Widyaningrum P, Adfa M. (2017). Determination of the major compounds in the extract of the subterranean termite Macrotermes gilvus Hagen digestive tract by GC-MS method. Ukrainian Biochem. J., 89(4): 77-82.

[9] da Costa RR, Hu H, Pilgaard B, Vreeburg SM, Schückel J, Pedersen KS, Kračun SK, Busk PK, Harholt J, Sapountzis P, Lange L. (2018). Enzyme activities at different stages of plant biomass decomposition in three species of fungus-growing termites. Appl. Environ. Microbiol., 84(5): e01815-17.

[10] Meyer VW, Braack LEO, Biggs HC, Eberson C. (1999). Distribution and density of termite mounds in the Northern Kruger National Park, with specific reference to those constructed by Macrotermes holmgren (Isopteran: Termitidae). African Entomol., 7: 123-130. 